\title{
CALL CENTRE WORK AND HEALTH AND SAFETY ISSUES
}

\author{
Vivienne Hunt, Erling Rasmussen and Felicity Lamm \\ University of Auckland and AUT University
}

\begin{abstract}
The international research on call centre employment presents a mainly negative view of the nature of this work. A more positive portrayal of call centre work has been demonstrated in some New Zealand research, highlighting the problem of generalising across different contexts. Previous New Zealand research has also found variation in terms of employment outcomes, job satisfaction and career opportunities across various industries, type and size of call centre and different management approaches. This paper continues to explore the work experiences of call centre workers and is based on research in New Zealand conducted in public sector call centres. Insights from focus groups of trade union delegates informed the development of a survey which was circulated across 22 organisation, drawing responses from 845 call centre workers. The findings show that over half of the workers consider their call centre work is enjoyable most of the time, their work is strategically important and there are a number benefits. The benefits include career enhancements, new skills and developing social capital. However, despite the positives described in open ended survey questions and the ranking of attributes important to call centre workers, almost half of the respondents have health concerns about the nature of their work or the call centre workplace. It is this particular finding that is the focus of the paper. It illustrates the need for an occupational health focus to be extended to call centre employment in New Zealand.
\end{abstract}

\section{Introduction}

There has been considerable research on call centres with much academic interest focussed on the labour process used in call centre employment and a common theme of the international research has been the criticism of the call centre workplace and the practices used within it. Many studies demonstrate that stress and the nature of call centre jobs leads to the high levels of staff attrition, sickness and/or health problems (Callaghan \& Thompson, 2001, 2002; Holman, Batt, \& Holtgrewe, 2007; Taylor \& Bain, 1999; van den Broek, 2004).

The extensive range, depth and spread of the literature reflects keen academic interest as call centres provide an interesting and unique loci for exploring contemporary work. The use of standardised work practices in call centres to deliver service with the adoption of technology to measure human performance have provided fruitful research directions. Such research has become more important as the number of call centre employees continues to grow, representing a signification proportion of the paid workforce in many countries. A question behind the research undertaken for this paper is whether call centres provide decent work and whether the negative portrayal of the nature of work in studies located in the UK, Australia and Europe is representative of the New Zealand context.

To date the research undertaken on employment in New Zealand call centres have shown mixed evidence. One study suggests the work meets the New Zealand Department of Labour's definition of precarious work
(Hannif \& Lamm, 2004). The same data was analysed for evidence of occupational health and safety concerns and found in two contrasting case studies that workers facing certain health risks are a result of their call centre work practices (Hannif \& Lamm, 2005). An earlier study demonstrated that the adoption of technology in bank call centres was both enabling and beneficial for new skills development (Sayers, Barney, Page, \& Naidoo, 2003), while an ethnographic study on a call centre offering social services found call centre workers had problems reconciling their front line work with their non-work lives (Copas 2004). Case study research across six sectors explored the work experience of promoted female call centre workers and found many positive accounts of career trajectories and the call centre work experience (Hunt, 2004a, 2004b, 2006, 2008; Hunt \& Rasmussen, 2006 2007; Hunt, Rasmussen, \& Lamm, 2006). While Hunt (2008) does not claim such findings are generalisable across call centres, her research suggests a more positive image of call centre work is possible. She found that the call centre work experience of new entrants to the labour market - for example, immigrants, students or return-to-work mothers - can be invaluable for career progression externally or within call centres.

Despite the large body of research on call centres, little is known about the occupational health and safety (OHS) policies and practices used in these workplaces. There has been scant research on the health and safety experiences of New Zealand call centre workers. Hannif and Lamm (2005) sought to address that gap by examining whether the tasks performed and the OHS policies and practices in call centres made the job dangerous or unhealthy for workers. Case study methodology was used to explore such questions in two call centres, selected to epitomise the diversity that exists 
in the industry. Their findings based on interviews with case study participants and key stakeholders showed that OHS policies and practices in these call centres represented various risks with negative OHS outcomes demonstrated by a lack of organisational compliance with the New Zealand employment legislation (Hannif \& Lamm, 2005).

Internationally the occupational health problems in call centres were first noted as early as 1999 when a study was initiated by London School of Economics and International Federation of Commercial, Professional and Technical Employees (FIET). The British affiliate in the banking sector, BIFU at this time had drawn attention to the increased risk of Repetitive Strain Injury (RSI) to which telephone operators are exposed because of their constant use of the computer. The union had also detected that operators in the call centres were losing their voices, with the worst affected being part-time employees who could work up to five hours without a break (Demaret, Quinn, \& Grumiau, 1999).

While many studies on call centre work have noted the stressful nature of the job, the concern about health issues in call centres was not systematically researched until Taylor et al. (2003) investigated a former public utility in central Scotland. Their work explored the physical and social work environment of the call centre using a combination of qualitative and quantitative method. This included responses $(n=634)$ to a self-completed questionnaire to gain information from call handlers $(74 \%$ of respondents) and non-customer facing respondents about frequency of health complaints and reports on their levels of discretion and control. They also sought information on physical working conditions and their findings highlight the importance of having a framework that management and workers agree to work within. While they question whether "one can generalise from $a$ single case study .... to call centres more broadly" they suggest that unless radical change in work organisation in call centres is instituted, widespread work-related ill health will be persistent within the call centre environment (Taylor, Baldry, Bain, \& Ellis, 2003).

In their paper on occupational safety and health in the New Zealand call centres Hannif and Lamm (2005) note too, a "muted discussion" on the impact of call centre practices on the health of the workers. Similarly our paper explores concerns raised about health in call centre employment. The study was initiated by a trade union seeking to measure quality of work-life, as it gathered evidence about how workers felt about call centre employment. Questions about what attributes of the call centre job are enjoyed, what aspects of the job are important and key worker concerns, were included in the research. More importantly the study asked workers what they would like to change if they could. Initiated in 2008 and completed in 2009, using mixed methods of focus groups and responses to a self-completed email questionnaire, the study gathered responses from call centre representatives $(n=845)$ and union delegates $(n=$ 45). Respondents worked in 22 call centres operated by the public service sector which represents the largest segment of call centre employment in New Zealand.

\section{Health and Safety in New Zealand}

Health and safety issues associated with call centre employment must also be seen in its wider context of regulatory and public debate of occupational health and safety (OHS) issues. In the last two decades, there has been considerable pressure to adjust OHS legislation and workplace practices in New Zealand. The pressure has been generated by: a perceived inadequate legislative approach; high profile court cases (legal precedent); an unsustainable rise in accident compensation expenditures; and rising public concerns about work-life balance and stress issues.

The perceived inadequate legislative approach has prompted two major legislative reforms - the Health and Safety in Employment Act 1992 and the Health and Safety in Employment Amendment Act 2002 (see Lamm, 2009). These reforms have moved towards "one act and one enforcement authority" and have ushered in a new approach to OHS management with an emphasis on workplace hazard identification and prevention (Hannif and Lamm, 2004). Thereby the main responsibility and accountability for OHS rests primarily with the employer, and this has become a major managerial pre-occupation. The message to take OHS "seriously" has also been bolstered by financial penalties and incentives being increased dramatically: there are higher fines available; there have been several high profile court cases awarding large compensations; and organisations are faced with higher accident insurance premiums or rebates associated with a stellar OHS prevention record (Rasmussen and Anderson, 2010). The Amendment Act 2002 also introduced OHS committees for organisations with more than 30 employees, and with active union support, it appears likely that OHS issues will be a common agenda item in many managerial meetings (Lamm, 2010).

In terms of call centre employment, the focus on work environment, stress and work-life balance has been particularly important. There has been more emphasis on ergonomics and noise (hearing aids subsidies being a major accident compensation expenditure), with the Department of Labour sponsoring several intervention campaigns. Stress and fatigue are now recognised as a potential work hazard in the New Zealand legislation, following a handful of legal precedent creating court decisions where employers received substantial fines (Caisley, 2004: 71). This has put the spotlight on the intensive nature of working in call centres, and countering stress and fatigue has been a topic at conferences held in New Zealand and Australia (Hannif \& Lamm, 2005). While ergonomics, stress and fatigue are obvious targets in a call centre environment, some research has suggested that some work-life balance issues can be solved by appropriate call centre scheduling and managerial attendance to employee needs (Hunt and Rasmussen, 2006). 


\section{Research Method}

Qualitative insights about the issues facing public services call centre workers were first gained by holding focus groups with trade union delegates. Three focus groups attracted around 45 delegates from across New Zealand, and their discussions and concerns about call centre work were recorded and transcribed. These transcripts were analysed and used to develop the questionnaire that had been used in earlier surveys of call centre workers (see Hunt 2008). An internet-based questionnaire link was emailed to delegates across 25 call centres, and members were encouraged to complete the survey. At most of the call centres, management supported the survey being completed during work time, which probably assisted in 845 surveys being returned. Most of the respondents were entry-level workers from 17 different call centres. The findings from the survey are presented below, using a combination of statistical software SPSS and Nvivo.

\section{Respondent Characteristics}

\section{Table 1: Gender $(\mathrm{N}=845)$}

\begin{tabular}{|l|r|r|r|}
\hline & Freq & Percent & $\begin{array}{r}\text { Valid } \\
\text { Percent }\end{array}$ \\
\hline Missing & 17 & & \\
Female & 620 & 73.4 & 73.4 \\
Male & 208 & 24.6 & 24.6 \\
Total & $\mathbf{8 4 5}$ & $\mathbf{1 0 0 . 0}$ & $\mathbf{1 0 0 . 0}$ \\
\hline
\end{tabular}

Table 2: Position in Organisation

\begin{tabular}{|r|r|r|}
\hline & Frequency & Percent \\
\hline CSR & 679 & $80.36 \%$ \\
\hline Other & 71 & $8.40 \%$ \\
\hline Professional/Technical & 40 & $4.73 \%$ \\
\hline Team Leader & 34 & $4.02 \%$ \\
\hline Case Coordinator & 1 & $0.12 \%$ \\
\hline CC Manager & 1 & $0.12 \%$ \\
\hline HelpDesk & 1 & $0.12 \%$ \\
\hline Representative & 1 & $0.12 \%$ \\
\hline Social Worker & 1 & $0.12 \%$ \\
\hline Missing & 16 & $1.89 \%$ \\
\hline Total & $\mathbf{8 4 5}$ & $\mathbf{1 0 0 . 0} \%$ \\
\hline
\end{tabular}

Seventy nine percent of respondents completing the survey were employed full time (see table 3), and seventy four percent belonged to the largest union. Nineteen percent (159) recorded that they did not belong to any union, and 2\% (16) reported they belonged to an "other" unspecified union. Cross tabulations shows that $23 \%$ of those who do not belong to the union were employed part time.
Table 3: Employment Contracts

\begin{tabular}{|l|r|r|}
\hline & $\mathbf{N}$ & \% of Total \\
\hline Full Time & 671 & $79 \%$ \\
\hline Part time & 143 & $17 \%$ \\
\hline Fixed Term & 5 & $1 \%$ \\
\hline Missing & 26 & $3 \%$ \\
\hline & $\mathbf{8 4 5}$ & $\mathbf{1 0 0 \%}$ \\
\hline
\end{tabular}

\section{Qualification Levels}

Respondents demonstrated that they were reasonably well qualified, with $32 \%$ having University-level qualifications, $21 \%$ having college and polytechnic diplomas, and 11\% having trade certificates (see Table 4).

\section{Table 4: Tertiary Qualifications}

\begin{tabular}{|lll|}
\hline & Frequency & Percent \\
University & 274 & $32 \%$ \\
College & 176 & $21 \%$ \\
$\begin{array}{l}\text { Polytechnic } \\
\text { diploma }\end{array}$ & 179 & $21 \%$ \\
$\begin{array}{l}\text { Other trade } \\
\text { certificates }\end{array}$ & 97 & $11 \%$ \\
Missing & 119 & $14 \%$ \\
& $\mathbf{8 4 5}$ & $\mathbf{1 0 0 \%}$ \\
\hline
\end{tabular}

\section{Importance of Call Centre Work}

The questionnaire was designed to seek to understand the attributes of the call centre job that were important to workers. Employees were asked to agree or disagree with a number of statements as to what was important in the job using a scale of 1 to 5 where 1 was strongly agree and 5 was strongly disagree. Table 5 below notes the mean rating of all responses. The strongest positive response was a mean of 2.00 to the statement that "call centre work is strategically important". This was followed by "the supervisor is helpful" (mean of 2.05). The strongest negative reaction (disagree) was 4.02 recorded against the statement that "being time efficient is more important than fully addressing the customer query" (see Table 5).

\section{Table 5 goes here}

The results indicate that the call centre workers consider their work is important; that they have some control and discretion over their jobs; and that they learn technical skills. A neutral response to "monitoring is meaningful" contrasts many of the international studies on this aspect. (See for example, Deery, Iverson, \& Walsh, 2002; Demaret et al., 1999; Holman, 2002; Houlihan, 2000; Kjellseup, 2001; Poynter, 2000; Union Research Centre 
for Organisation and Technology, 2000; van den Broek, 2004; Yeuk-Mui, 2001)

\section{Why Work in a Call Centre?}

Much of the international research which deplores call centre employment has not established why workers continue to seek jobs at call centres. To understand more about this motivation, respondents were asked to rank a number of statements about what had attracted them to work in their current call centre. The four reasons ranked most important or important (1 or 2) are noted in Figure 1 below. While hourly rate of pay was noted by half of the respondents, just over 60\% ranked "enhancing their careers" as most important, with the need to learn skills ranked as number three. This finding contradicts the international research findings which demonstrate career development opportunities are not consistent with working in call centres.

\section{Key Benefits of Call Centre Work?}

To understand more about what call centre employees found positive about their work, an open ended question

\section{Figure 1: Most Important Reasons for seeking job in CC}

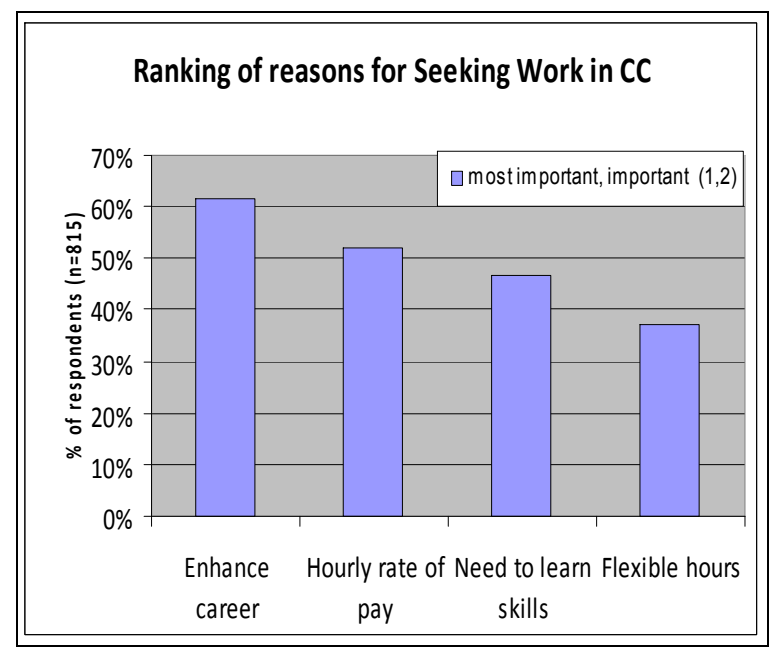

asked respondents to describe the key benefits of their job in their particular call centre. This generated a total of 756 written responses ( $88 \%$ of all respondents), and the analysis of these responses used Nvivo software to identify a number of key themes. The analysis is based on developing a code book and establishing nodes in order to group responses. The nvivo references show the number of references to the particular concern and a measure of the percentage coverage of the text. Table 6 shows that new skills and career prospects followed by conditions of employment and then job satisfaction are important to workers. The latter includes many references to flexible hours and hours that suit individual workers. Table 6 goes here
Verbatim responses demonstrate too that an important attribute of the call centre job is that it provides career prospects. Under the node "skill/career" there are a total of 404 references with "career prospects", "knowledge of the business", "customer and people skills" being noted most frequently. The references to conditions of employment are more widely spread however "hours that suit" and "flexible hours" contribute to over one hundred references. The third largest node that catergorises the most frequently mentioned benefits is "job satisfaction". This includes many mentions of "helping people" illustrating the importance of people gaining satisfaction from helping others in life. The following are illustrative examples of the type of verbatim responses recorded in Table 6.

\section{Node 1: New Skills/Career Prospects}

Learning about policies, government, work environment.

A great deal of scope for career development.

Gaining experience to further my career.

Work is immediate and satisfying.

I enjoy fast pace of work.

Node 2: Job Satisfaction

Huge sense of satisfaction when I know I've been instrumental in making a difference to someone.

The variety of work and the challenges provided by the role I am in.

Node 3: Conditions of Employment

Flexible Hours:

Being a working Mum, the hours suit me because I can take care of my youngest child, but at the same time be able to work.

Centrally located and easy to get to work.

\section{Node 4: Environment}

The environment is phenomenal, awesome bubbly and colourful workplace, the activities and benefits for coming to work not only makes you want to go to work but most importantly helps you feel comfortable

Fantastic working environment.

Node 5: Training and Support

The training was a good introduction to the role; it was in depth and good support whilst training.

I think that the on-the-job training is absolutely fantastic and the fact that this is always evolving and changing to meet the needs of staff is brilliant.

You learn a lot from your workmates when you are in a contact centre environment. 


\section{Health Concerns in Call Centres}

Following concerns raised by union delegates about health issues in call centres in the focus groups, an openended question was included in the survey with respondents being asked if they had any health concerns. If they replied yes they were asked to describe them. Table 7 below shows the results of categorising the openended written responses using Nvivo software.

The single largest response was OOS (occupational overuse syndrome) with 109 references made to OOS in the open-ended responses. The text coverage is slightly misleading as many responses were simply OOS. Some of the quotes below speak about: "Overuse (sore back, over use of hands, sore eyes, and sore tailbone), RSI in the wrists and arms, having to sit all day at a desk, hunching over all the time as well as eyesight deterioration from using keyboard and VDU all day."

The physical working environment is the next most frequently mentioned concern with 89 references, and the most frequently mentioned one being the air conditioning. Stress and mental health concerns are a frequently described health issue, and there are 67 coded references to this. The references to stress are mainly noted as different aspects of the job, for example, "constant noise in the ear", "constant call after call", "system failures" and "dealing with difficult calls and managing relationships with team leaders". The physical working environment is also included in mentions of stress. One quote, "being treated more as a labour unit rather than an individual", draws attention to the factory like organisation of a call centre operation. Contrasting the earlier neutral responses to a question on monitoring and supervision, "monitoring practices and team leaders" are noted as the cause of a stress and "intimidation". An often repeated quote mentions that management do not recognise the stress that customer service operators are under as attested by the following quote: "the managers here don't fully understand the stress our call centre staff are under from their customers".

\section{What Should Change}

One of the last questions in the questionnaire asked respondents to describe what they would just change if they could change just one thing at their current call centre workplace. This question generated a total of 199 responses which were also analysed and sorted into nodes using the Nvivo software (Table 8). The most commonly recorded response was around the "conditions of work". This included "pay", "flexitime" and "hours of work", with the latter being noted more frequently than pay. Management practices, the nature of work and the use of KPI's are another aspect that call centre workers would like to change. There are 31 mentions of the environment and team work, while health concerns are only raised 11 times. This is somewhat surprising given that so many respondents described concerns about health issues in the previous question. Variety of work and "upskilling opportunities" are mentioned confirming the desire to seek job variation given the repetitive nature of the work.

Tables 5 and 8 go here

\section{Discussion}

Given the international evidence on call centre employment, findings that suggest there are health concerns in call centres operated in New Zealand should not be surprising. The problems of stress, repetitive strain injury or occupational overuse syndrome as described above are similar to findings reported elsewhere. More surprising given New Zealand's employment law and emphasis on safety and health in employment is that these call centres are operated by the public sector, usually seen as an exemplary employer.

Apart from the exploratory study by Hannif and Lamm (2005), health issues in call centres were not detected in other New Zealand research. Hunt's research over four years found some evidence of concern from management about healthy food snacks because staff tended to be over weight which could be attritubable to stress and the sedentary nature of the work (Hunt, 2008).

The research finds contradictory evidence about the quality of the call centre work occupation. Workers, despite stated concerns about the occupational health of their jobs, seem to enjoy working in call centres. They find that the employment experience is useful for enhancing their career prospects. This suggests other attributes of the job outweigh the concerns workers may have about the health risks associated with the job.

The responses to questions about what workers enjoy and why they choose to work in call centres provides some clue as to attributes considered important to workers. Flexible work practices accommodating some work life balance, opportunities to meet and interact with people and work experience helping to gain employment elsewhere provide rational explanation as to why employees work in a call centre. What the research does not show is how long call centre workers stay at such workplaces and whether the turnover associated with the job helps manage the health issue or at least keeps it under wraps. Perhaps turnover helps to maintain the health of workers and is a necessary part of call centre employment?

\section{Conclusion}

It is clear that workers have mixed reactions to their employment in these public service call centres. Many enjoy the social and interactive nature of their work and claim that one key benefit is the job satisfaction they derive from assisting people over the phone. Some suggest they learn new skills and can enhance their career prospects by recording such a work experience on their CV's. 
Almost half of the respondents, however, feel that there are health concerns in their call centre job, with the key ones being Occupational Overuse Syndrome and stress. Surprisingly, when asked about the changes workers would introduce if they could, "addressing the health concerns" was not mentioned frequently. The physical environment, however, is noted as problematic with a key complaint being the operation of the air conditioning, not least for its role in the spread of sickness.

The research does not provide insights as to why workers who have health concerns about their employment would continue to work in the call centre. Further research needs to ascertain the choices workers have regarding other employment opportunities and establish whether call centre work is a job of last resort or a temporal solution to employment for a limited period. The research should seek to measure the impact of the health concerns on both the workers and the organisation. Answering such questions may be helpful for deciding whether this type of employment represents decent work.

Under the current occupational health and safety regime in New Zealand, it is evident that management is not taking responsibility for the health of their workers in the featured call centres. This could be taken up more proactively by the union delegates but with New Zealand currently experiencing rising levels of unemployment, it seems that job security may be a more important attribute than healthy employment.

\section{Bibliography}

Caisley, A. (2004) 'The law moves in mysterious ways.' In Rasmussen, E. (ed.) Employment Relationships: New Zealand's employment Relations Act. Auckland University Press, Auckland.

Callaghan, G., \& Thompson, P. (2001). Edwards revisited: Technical control and call centres. Economic \& Industrial Democracy, 22(1), 13-37.

Callaghan, G., \& Thompson, P. (2002). 'We recruit attitude': The selection and shaping of routine call centre labour. Journal of Management Studies, 39(2), 233-254.

Deery, S., Iverson, R., \& Walsh, J. (2002). Work relationships in telephone call centres: Understanding emotional exhaustion and employee withdrawal. Journal of Management Studies, 39(4), 471-496.

Demaret, L., Quinn, P., \& Grumiau, S. (1999, 27 Feb 2006). Call Centres - The New Assembly Lines. Retrieved 10th March 2006, from http://www.icftu.org.

Hannif, Z., \& Lamm, F. (2004). Precarious Employment in the New Zealand Call Centre Industry. Labour, Employment and Work in New Zealand, 14.

Hannif, Z., \& Lamm, F. (2005). Occupation Health and Safety in the New Zealand Call Centre Industry ESC Working Paper No 2005/8 Retrieved 3rd March, 2006, from http://www.unionnetwork.org/uniindep.nsf//\$FILE/OHS-CC-NZ.pdf

Holman, D. (2002). Employee wellbeing in call centres. Human Resource Management Journal, Vol 12 (No 4), $35-50$.

Holman, D., Batt, R., \& Holtgrewe, U. (2007). The Global Call Centre Report: International Perspectives on Management and Employment. New York: Cornell University.

Houlihan, M. (2000). Eyes Wide Shut? Querying the depth of call centre learning. Journal of European Industrial Training, 24(2,3,4), 228..240.

Hunt, V. (2004a). Call Centre Work : Careers for Women? International Employment Relations Review, 10(2), 111-131.

Hunt, V. (2004b). Call Centre Work for Women: Career or Stopgap? Labour and Industry, 14(3), 139 -153.

Hunt, V. (2006). Call Centres Get Women back to Work. New Zealand Herald,

Hunt, V. (2008). Call Centre Work-Careers for Women Exploring the Work Experience of Women Working In New Zealand call centres. Unpublished Doctorate, University of Auckland, Auckland.

Hunt, V., \& Rasmussen, E. (2006 ). Call Centre Employment: Helping to Juggle Work Life Balance. Paper presented at the International Labour Process Conference. London 2006 Birkbeck University.

Hunt, V., \& Rasmussen, E. (2007). Turnover and Retention in a Tight Labour Market: Reflecting on New Zealand Research. Paper presented at the AIRANZ. Auckland, 2007. University of Auckland.

Hunt, V., Rasmussen, E., \& Lamm, F. (2006). From Black and White to Shades of Grey: Research of Call Centre Employment, . Paper presented at the Labour, Employment and Work Conference. Wellington, 2006. Victoria University.

Kjellseup, N. (2001, 2001). Unions and the Benefits of Call Recording. Retrieved 2001, 2001, from www.callcentres.com.au

Korczynski, M. (2003). Communities of coping: Collective emotional labour in service work. Organization, 10(1), 55-79.

McManus, B. (2006, 17th August). India's gain could be Australia's loss,. Retrieved 21st August 2006, 2006, from http://www.theage.com.au/news/tv-radio/comparing-callcentres/2006/08/16/1155407816573.html 
Mulholland, K. (2002). Gender, emotional labour and teamworking in call centre. Volume 31(Number 3), 283303.

Munro, C. (2006). Aussie bid to reverse call centre jobs drain

Journal, (May 28, 2006). Retrieved from http://www.smh.com.au/news/national/aussie-bid-toreverse-call-centre-jobsdrain/2006/05/27/1148524933953.html\#

NASSCOM-McKinsey Report. (2002). Robust Growth for Indian IT Services and IT Enabled Services Industry. from http://www.products.nasscom.org/

Pandian, S. (2006). Globalisation and Development: Impact on Indian Women Workers Retrieved 15th August, 2006, from http://www.capstrans.edu.au/about/projects/globaldev.html\#top

Poynter, G. (2000 ). 'Thank you for Calling'..The Ideology of Work in the Service Economy'. Telematics and Informatics, Soundings,(14, Spring), 151-160.

Sator, C. (2006). British companies recalling their call centres from India. Retrieved 28th June 2006, from http://news.monstersandcritics.com/business/article 1175 957.php/British companies recalling their call centres from India

Sayers, J., Barney, A., Page, C., \& Naidoo, K. (2003). A Provisional "Thumbs Up" to New Zealand Bank Call Centres. University of Auckland Business Review, 5(1), 30-40.

Sechu, G. (2003). The Global Beck and Call Service: Stress in the sunshine sector. Retrieved July 20, 2005, from http://www.indiatogether.org/2003/jul/womgendbudg.htm

Srivastava, S., \& Theodore, N. (2006). Off-Shoring: The View from Wall Street. In J. Burgess \& J. Connell (Eds.), Developments in the Call Centre Industry (pp. 10-50). Oxon: Routledge.

Taylor, P., \& Bain, P. (1999). An assembly line in the head: work employee relations in the call centre. Industrial Relations Journal, 30(2), 101-117.

Taylor, P., \& Bain, P. (2004). No Passage to India? UK Unions, Globalisation and the Migration of Call Centre Jobs. Paper presented at the Work Employment and Society, 2004, Manchester.

Taylor, P., \& Bain, P. (2005). 'India calling to the far away towns': the call centre labour process and globalization. Work Employment and Society, 19(2), 261282.

Taylor, P., Baldry, C., Bain, P., \& Ellis, V. (2003). 'A unique working environment': health, sickness and absence management in UK call centres. Work Employment and Society, 17(3), 435-458.

Union Research Centre for Organisation and Technology. (2000). Call Centres: What kind of future workplaces? Retrieved 10th March, 2006, from http://www.ohsrep.org.au/storage//documents/Call\%20Ce ntres\%20URCOT\%20report.rtf

van den Broek, D. (2004). Monitoring and Surveillance in Call Centres : Some Responses from Australian Workers. Labour and Industry, 12 (3).

Wong , W. M. (2006). Singapore call centres ranked second in survey of six Asian countries. Singapore News Retrieved 5th July, 2006, from http://www.channelnewsasia.com/stories/singaporelocaln $\underline{\text { ews }}$

Yeuk-Mui, M. T. (2001). Information technology in frontline service work organization. Journal of Sociology, 37(2), 177-206.

Zapf, D., \& Holz, M. (2006). On the positive and negative effects of emotion work in organizations. European Journal of Work and Organizational Psychology, 15(1), 1. 
TABLE 5: WHAT IS IMPORTANT IN THE CC JOB

\begin{tabular}{|l|r|r|}
\hline $\begin{array}{l}\text { Statements that workers were asked to rate on a scale from 1 to 5 } \\
\text { (with 'strongly agree' being } \mathbf{1} \text { and 'strongly disagree' being 5) }\end{array}$ & $\begin{array}{r}\text { Mean } \\
\text { Ratings }\end{array}$ \\
\hline Being time efficient is more important than addressing customer query & 827 & 4.02 \\
\hline Outsourcing is a concern & 825 & 3.77 \\
\hline Pay rates are good & 822 & 3.25 \\
\hline Rest of Org is positive to the call centre & 825 & 3.09 \\
\hline Managers listen to my concerns & 828 & 2.97 \\
\hline I have control over my work & 826 & 2.90 \\
\hline Monitoring is meaningful & 822 & 2.89 \\
\hline HR staff are helpful & 823 & 2.64 \\
\hline I enjoy my work most of the time & 828 & 2.48 \\
\hline Unions are important & 828 & 2.41 \\
\hline Environment is good & 825 & 2.41 \\
\hline Technology enables me to do my job & 831 & 2.29 \\
\hline I have learned technical skills & 825 & 2.21 \\
\hline Collective Bargaining is important & 821 & 2.14 \\
\hline Supervisor is helpful & 830 & 2.06 \\
\hline Call centre work is strategically important & 827 & 2.00 \\
\hline
\end{tabular}




\begin{tabular}{|c|c|c|}
\hline & & $\begin{array}{r}\text { No. of } \\
\text { References }\end{array}$ \\
\hline \multicolumn{2}{|c|}{ New SkillsiCareer } & 404 \\
\hline \multirow[t]{8}{*}{ Node 1} & Career Prospects & 107 \\
\hline & Knowledge of Organisation's Business & 97 \\
\hline & Communication, Customer Service, People Skills & 96 \\
\hline & New Skills Learned & 61 \\
\hline & General Work Experience & 60 \\
\hline & Computer Skills & 33 \\
\hline & Working for Govt Dept or Corporation & 33 \\
\hline & Confidence - Personal Development & 24 \\
\hline \multicolumn{2}{|c|}{ Job Satisfaction } & 147 \\
\hline \multirow[t]{6}{*}{ Node 2} & Helping People & 49 \\
\hline & Working with and Meeting Different People & 40 \\
\hline & Fulfilling Work & 27 \\
\hline & Variety of Work/Diverse Roles/Challenging Work & 23 \\
\hline & Applying my Skills and Knowledge & 4 \\
\hline & Consistency & 4 \\
\hline \multicolumn{2}{|c|}{ Conditions of Employment } & 236 \\
\hline \multirow[t]{5}{*}{ Node 3} & Pay/Financial Incentives/Benefits & 84 \\
\hline & Hours Suit Me & 79 \\
\hline & Flexible Hours & 30 \\
\hline & Conditions of Employment & 25 \\
\hline & Other & 18 \\
\hline \multicolumn{2}{|c|}{ Environment } & 165 \\
\hline Node 4 & Environment & 68 \\
\hline Node 5 & Training and Support & 54 \\
\hline Node 6 & Physical Environment & 37 \\
\hline Node 7 & Fun/Friendly Place to Work & 6 \\
\hline
\end{tabular}


Nvivo Analysis of Text References by Node

Node

No.

Description of Node

$\%$ Coverage Text

Total Ref

$1 \quad$ OOS Related

$4.01 \%$

OOS/RSI mentions

109

Sore fingers/wrists

2 Physical Working Environment

$7.64 \%$

Air-Conditioning

Seats/Equipment

Easy to get sick in $\mathrm{CC}$

3 Stress /Mental Health

$4.65 \%$

Stress

Mental Health

4 Eyesight/ Hearing Related

$2.40 \%$

Eye/Vision Impairment

40

Hearing Problems

7

5 Sedentary Nature of job

$3.09 \%$

6 Back, Neck, Shoulder Complaints

$1.84 \%$

Back

Neck/Shoulders

4

$7 \quad$ Other

$2.62 \%$

Headaches

4

Sore Throats

2

Posture Problems

2

Exhaustion

1

Bullying

1

Breaks

3

8 Sick Leave Issues

$0.71 \%$ 
1 Repetitive work has lead to some discomfort in my arms, back and hands.

RSI in wrists and arms, etc.

Overuse (sore back, over use of hands, sore eyes, sore tail bone).

Just normal hazards when working with keyboard/computer.

2 Just the normal OOS issues, repetitive work.

Illnesses spread through air conditioning.

Working in such a closed environment there are often times when you get sick due to so many other people being sick and the air conditioning carries this round.

People having to come into work because of the high level of calls, and most of the people at the call centre are sick. This puts stress on people and others get sick at the same time.

Women workers having to walk alone along dark streets after shifts due to lack of parking provided.

3 Mental and emotional stress are not "recognized" enough.

The job is stressful and not enough recognition has been given to this.

Constant noise in the ear, constant call after call, system failures cause lots of stress.

$4 \quad$ Stress! Both from customers, and management, not a day goes by where we don't get abusive callers. The nature of our customers range from beneficiaries, mental health patients to ex prisoners, as well as immigrants with little English.

Deterioration of eye-sight from using and concentrating on computers daily for long periods of time. Personally my eyesight has gradually gotten worse but that's because my previous job didn't involve me sitting in front of a TV screen all day.

I have also become slightly short sighted since working here. Up until earlier this year I had pretty much perfect eye sight.

Hearing tends to be affected with the different volumes of call coming in daily which give me migraines sometimes but not often. Also vision gets affected with constantly looking into a computer PC.

Computer damaging my eye-sight. Also head phones can affect my hearing on one side.

5 The inactivity of the job. I have gained a lot of weight as well as health problems since joining. Sitting constantly all day without being able to get up and move around while doing work. Increased weight due to sitting for the whole day.

6 Back issues - sitting on a phone all day.

Long hours on phone/computer can cause back problems.

Tensed back and shoulders will lead to back pains and headaches.

Sitting for long periods - lower back pain, aching arms and upper back pain from repetitive typing.

7 I get migraines from the lights.

Headaches from staring at a PC constantly.

Voice strains, constant talking can be aggravating to the voice.

Can get cancer with earphone close to your brain.

8 Sick leave is high. This may be a symptom of Call Centre work.

High rate of sick leave. 
Table 8: Analysis of Key THEMES: Responses to Question about what would you change?

\begin{tabular}{|c|c|c|}
\hline $\begin{array}{l}\text { Node } \\
\text { Description }\end{array}$ & $\begin{array}{l}\text { \# of Refs } \\
(\% \text { text })\end{array}$ & References included in the node \\
\hline Nature of Work & $\begin{array}{l}119 \\
(11.4 \%)\end{array}$ & $\begin{array}{l}\text { Specific mention of job tasks/duties. Includes mention of need for variety; } \\
\text { dealing with difficult customers. } \\
\text { Desire to "upskill"/train/do "greentime work"/move around departments. }{ }^{1}\end{array}$ \\
\hline $\begin{array}{l}\text { KPIs, QC and } \\
\text { Compliance } \\
\text { Issues }\end{array}$ & $\begin{array}{l}87 \\
(6.5 \%)\end{array}$ & $\begin{array}{l}\text { Includes mention of any “AHT” (Average Handling Time). } \\
\text { “ADH”(Adherence); “ } \boldsymbol{C H T} \text { ” (Call Handling Time); and other QC measures that were } \\
\text { part of KPI's. } \\
\text { Key Performance Measurements / reporting / monitoring / targets / performance } \\
\text { appraisal measures. }\end{array}$ \\
\hline $\begin{array}{l}\text { Conditions of } \\
\text { Employment }\end{array}$ & $\begin{array}{l}174 \\
(7.4 \%)\end{array}$ & $\begin{array}{l}\text { Any mention of general conditions of employment (e.g. pay levels, hours, workloads, } \\
\text { rosters). } \\
\text { Annual leave provisions (allowances for "flexi-time”, breaks, staffing levels). } \\
\text { Pay } \\
\text { Flexi-time } \\
\text { Hours of work }\end{array}$ \\
\hline
\end{tabular}

\footnotetext{
${ }^{1}$ May also be double coded under "Management Practices"
} 